\title{
PEMBUATAN KARBOKSIMETIL SELULOSA DARI KULIT PISANG KEPOK DENGAN VARIASI KONSENTRASI NATRIUM HIDROKSIDA, NATRIUM MONOKLOROASETAT, TEMPERATUR DAN WAKTU REAKSI
}

\author{
SYNTHESIS OF CARBOXYMETHYL CELLULOSE FROM BANANA PEEL \\ WITH VARIATIONS OF SODIUM HYDROCIDE AND SODIUM \\ MONOCHLOROACETAT CONCENTRATION, \\ TEMPERATURE AND REACTION TIME
}

\author{
Saputri Ayuningtiyas, Feni Dwi Desiyana, Siswarni MZ \\ Departemen Teknik Kimia, Fakultas Teknik, Universitas Sumatera Utara \\ Jl.Almamater Kampus USU, Medan 20155, Indonesia \\ *Email : saputriayuningtiyas5@gmail.com
}

\begin{abstract}
Abstrak
Carboxymethyl cellulose (CMC) merupakan suatu derivat selulosa yang larut dalam air (koloid hidrofilik) yang efektif untuk mengikat air sehingga memberikan tekstur yang seragam, meningkatkan kekentalan. Penelitian ini bertujuan untuk memanfaatkan kulit pisang kepok sebagai bahan baku pembuatan CMC dan menentukan kondisi yang paling baik dalam proses pembuatan CMC dari kulit pisang kepok. Bahan-bahan yang digunakan adalah kulit pisang kepok, air, aquades, $\mathrm{NaOH}$, Natirum monokloroasetat dan asam asetat glasial. Varibel berubah dalam penelitian ini adalah konsentrasi $\mathrm{NaOH}$, massa natirum monokloroasetat, temperatur dan waktu reaksi. Pada penelitian ini terdiri dari empat tahap yaitu persiapan bahan baku, alkalisasi, karboksimetilisasi, dan netralisasi. Hasil penelitian diperoleh derajat subtitusi tertinggi sebesar 0,73 - 0.812 dengan konsentrasi $\mathrm{NaOH} 20 \%$ dan temperatur $45^{\circ} \mathrm{C}$, rasio mol selulosa: natirum monokloroasetat 1:1,6 dengan waktu reaksi 120 menit. Analisa FTIR menunjukkan keberadaan dari gugus fungsi $\mathrm{O}-\mathrm{H}, \mathrm{C}-\mathrm{H}, \mathrm{C}=\mathrm{O}, \mathrm{C}-\mathrm{O}, \mathrm{CH}_{2}$ dan $1,4 \beta$-glikosida yang diketahui memiliki gugus fungsi yang sama dengan karboksimethil selulosa komersial.
\end{abstract}

Kata kunci : Selulosa, Alkalisasi, Karboksimetilasi, CMC, Derajat subtitusi

\begin{abstract}
Carboxymethyl cellulose $(C M C)$ is a derivative cellulose which is soluble an in water (hydrophilic colloid). This material effective to bind water to provide a uniform texture and increase viscosity. The aim of this study is to utilize banana peel as a raw material to synthesis CMC and determine the best conditions in the process of synthesis CMC from banana peel. The materials used were banana peel, water, aquades, $\mathrm{NaOH}$, Natirum monochloroacetat and glacial acetic acid. The variables in this study were $\mathrm{NaOH}$ concentration, natirum monochloroacetat mass, temperature and reaction time. In this research consists of four stages there are preparation of raw materials, alkalization, carboxymethylation, and neutralization. The results of this research shows the variatioon $\mathrm{NaOH}$ concentration $20 \%$ and temperature of $45^{\circ} \mathrm{C}$ degree, mol rasio of cellulose:sodium monochloroacetat 1:1,6 with a reaction time of 120 minutes obtained the highest substitution degree of 0,73-0.812. The FTIR analysis shows the presence of the $\mathrm{O}-\mathrm{H}, \mathrm{C}-\mathrm{H}, \mathrm{C}=\mathrm{O}, \mathrm{C}-\mathrm{O}, \mathrm{CH} 2$ and 1,4 $\beta$-glycoside function groups known to have the same function groups as the commercial carboxymethyl cellulose.
\end{abstract}

Keywords: Cellulose, Alkalization, Carboxymethylation, CMC, Degree of substitution

\section{Pendahuluan}

Carboxymethyl cellulose (CMC) merupakan molekul anionik yang mampu mencegah terjadinya pengendapan protein pada titik isoelektrik dan meningkatkan viskositas produk pangan, disebabkan bergabungnya gugus karboksil CMC dengan gugus muatan positif dari protein [9]. Menurut BPS (2016) [1], penggunaan CMC setiap tahunnya mengalami peningkatan dan tercatat hingga 2016 data impor CMC mencapai $552.532 \mathrm{~kg}$ perbulan nya [1].
Hal ini menunjukkan bahwa kebutuhan masyarakat terhadap CMC sangat tinggi.

Pada mulanya CMC dibuat dari selulosa kayu karena kandungan selulosanya yang tinggi [5]. Dewasa ini CMC dikembangkan dari bahan bukan kayu yang mengandung selulosa seperti kulit pisang. Kulit pisang kepok terdapat kandungan selulosa yang cukup tinggi yaitu $17,04 \%$ sehingga kulit pisang kepok berpotensi untuk dimanfaatkan sebagai bahan baku pembuatan CMC [2]. 
Adapun beberapa penelitian yang dilakukan dalam pembuatan CMC dari bahan yang bukan kayu salah satunya dilakukan oleh Pushpamalar, dkk., (2005) yang menggunakan limbah sagu sebagai bahan baku dengan variasi pelarut salah satu pelarutnya yaitu aquades. Selain itu, Pushpamalar, dkk., (2005) juga memvariasikan variabel konsentrasi $\mathrm{NaOH}$ dan temperatur pada tahap alkalisasi, serta variasi waktu dan massa Natirum monokloroasetat pada tahap karboksimetilisasi. Pada penelitiannya Pushpamalar, dkk., (2005) meraih derajat substitusi (DS) yang cukup tinggi yaitu 0.821 pada variasi konsentrasi $\mathrm{NaOH}$, dan 0,768 pada variasi massa Natirum monoklor oasetat.

Berdasarkan penelitian Pushpamalar, dkk., (2006) dilakukan dengan menggunakan bahan baku kulit pisang, pelarut aquades dengan variasi konsentrasi $\mathrm{NaOH}$ dan temperatur pada tahap alkalisasi, serta variasi waktu dan massa Natirum monokloroasetat pada tahap karboksimetilisasi [6].

Penelitian ini bertujuan untuk memanfaatkan kulit pisang kepok sebagai bahan baku pembuatan CMC dan menentukan kondisi yang paling baik dalam proses pembuatan CMC dari kulit pisang kepok.

\section{Teori}

Karboksimetil selulosa merupakan polimer selulosa linear dan berupa senyawa anion, yang bersifat biodegradable, tidak berwarna, tidak berbau, tidak beracun, butiran atau yang larut dalam air namun tidak larut dalam pelarut organi [5]. Faktor utama yang perlu diperhatikan dalam pembuatan CMC adalah alkalisasi dan karboksimetilasi karena menentukan karakteristik CMC yang dihasilkan.

Pada tahap alkalisasi serat selulosa akan mengembang, yang menyebabkan struktur kristalin selulosa akan berubah dan meningkatkan kemampuan kimia masuk ke dalam serat. Selain itu, fase cair (campuran alkohol-air) sebagai agen solvasi, melarutkan $\mathrm{NaOH}$ dan mendistribusikannya ke gugus hidroksil selulosa membentuk alkil selulosa. Larutan $\mathrm{NaOH}$ akan menembus ke struktur kristal selulosa, kemudian mensolvasi gugus hidroksil yang membuatnya siap untuk reaksi eterifikasi dengan cara memutus ikatan hidrogen. Alkalisasi dilakukan menggunakan $\mathrm{NaOH}$, yang tujuannya mengaktifkan gugus-gugus $\mathrm{OH}$ pada molekul selulosa dan berfungsi untuk memudahkan difusi reagen pada tahap karboksimetilasi Pada proses karboksimetilasi digunakan reagen natrium monokloroasetat [7]. Pada tahap karboksimetilasi ini adalah proses eterifikasi. Pada tahap ini merupakan proses pelekatan gugus karboksilat pada struktur selulosa. Gugus karboksilat yang dimaksud terdapat pada asam natrium monokloroasetat. Jumlah natrium monokloroasetat yang digunakan akan berpengaruh terhadap substitusi dari unit anhidroglukosa pada selulosa. Bertambahnya jumlah alkali yang digunakan akan mengakibatkan naiknya jumlah garam monokloroasetat yang terlarut, sehingga mempermudah dan mempercepat difusi garam monokloroasetat ke dalam pusat reaksi yaitu gugus hidroksil [3].

\section{Metodologi Penelitian \\ Bahan Dan Peralatan}

Bahan yang digunakan dalam penelitian ini adalah kulit pisang kepok yang berwarna kuning, sudah matang dan masih segar yang kami peroleh di pasar pagi setia budi medan, aquadest, natrium hidroksida $(\mathrm{NaOH})$, natrium monokloroasetat dan asam asetat glasial $\left(\mathrm{CH}_{3} \mathrm{COOH}\right)$. Alat utama yang digunakan adalah waterbath, oven, kertas saring whatman, beaker glass, Erlenmeyer, ayakan 100 mesh, pH meter, alat titrasi, spektrofotometer FTIR, dan viskosimeter brookfield.

\section{Persiapan Bahan Baku}

Kulit pisang dicuci dan dibersihkan dari kotoran dan dikeringkan dibawah sinar matahari hingga kering dan sampai mudah untuk dipatahkan. Kulit Pisang kepok dihaluskan dengan menggunakan blender dan ayakan 100 mesh, dikeringkan kembali dengan oven pada suhu $60{ }^{\circ} \mathrm{C}$ selama 1 jam. Tepung kulit Pisang ditimbang sebanyak $10 \mathrm{~g}$ dan dimasukkan ke dalam erlenmeyer $250 \mathrm{ml}$, ditambahkan aquades sebanyak $160 \mathrm{ml}$ dan diikuti dengan penambahan $2 \mathrm{ml}$ asam asetat glasial. ditutup permukaannya dengan menggunakan gabus. Campuran dipanaskan dalam waterbath dengan suhu $70^{\circ} \mathrm{C}$ selama 3 jam, kemudian campuran disaring dan residu dicuci menggunakan aquades hingga $\mathrm{pH}$ netral dan terakhir dikeringkan dengan oven pada suhu $105^{\circ} \mathrm{C}$ hingga konstan.

\section{Prosedur Alkalisasi dan Karboksimetilasi}

Selulosa kulit pisang ditimbang sebanyak 5 gram, dimasukan kedalam erlenmeyer $250 \mathrm{ml}$ ditambahkan aquades sebanyak $100 \mathrm{ml}$ dan diikuti dengan penambahan $10 \mathrm{ml}$ dengan variasi konsentrasi $\mathrm{NaOH}$ masing masing 10\%, 20\%, $25 \%$ dan $30 \%$. Campuran diaduk dengan batang pengaduk selama 1 jam (60 menit). Kemudian ditambahkan Natirum monokloroasetat dengan variasi perbandingan rasio mol selulosa:Natirum monokloroasetat 1:0,5;1:1; 1:1,6 dan 1:2,3. Setelah itu campuran dipanaskan di waterbath 
dengan variasi suhu reaksi masing masing 35 ${ }^{\circ} \mathrm{C}, 40{ }^{\circ} \mathrm{C}, 45^{\circ} \mathrm{C}$ dan $50{ }^{\circ} \mathrm{C}$ dan dikocok dengan variasi waktu yaitu 60 menit, 120 menit, 180 menit dan 240 menit secara horizontal. Campuran disaring dan residu ditambahakan dengan $300 \mathrm{ml}$ aquadest dan direndam selama semalaman. Campuran dinetralkan dengan penambahan asam asetat glasial hingga $\mathrm{pH}$ mencapai 7, dan campuran disaring kembali dan dikeringkan dengan oven pada suhu $105^{\circ} \mathrm{C}$ hingga berat konstan.

\section{Hasil dan Pembahasan}

Pengaruh Variasi Konsentrasi $\mathrm{NaOH}(\%)$ dan Temperatur $\left({ }^{\circ} \mathrm{C}\right)$ Terhadap Derajat Subtitusi

Hubungan antara konsentrasi $\mathrm{NaOH}$ dan temperatur terhadap derajat subtitusi ditampilkan pada Gambar 1.

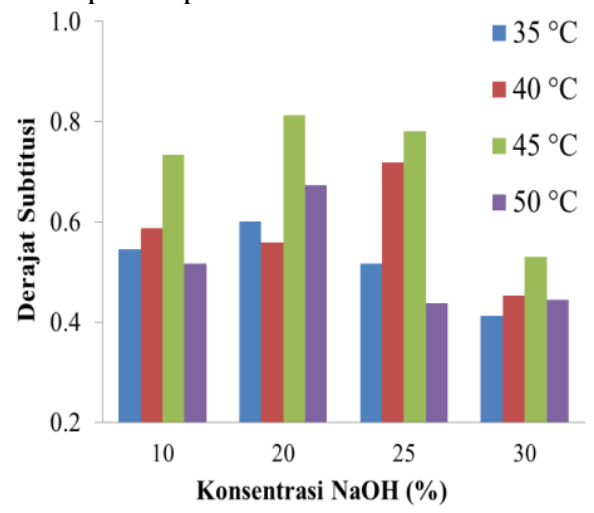

Gambar 1. Hubungan Derajat Subtitusi terhadap Variasi Konsentrasi $\mathrm{NaOH}(\%)$ dan Temperatur

Pada Gambar 1. dapat dilihat bahwa derajat subtitusi mengalami peningkatan seiring dengan meningkatnya konsentrasi $\mathrm{NaOH}$ yang diberikan, karena semakin banyak $\mathrm{NaOH}$, akan meningkatkan tingkat pengembangan selulosa dan memudahkan masuknya reagen Natirum monokloroasetat untuk mensubstitusi gugus hidroksil pada selulosa dengan gugus fungsi CMC [10]. Namun terdapat konsentrasi kritis $\mathrm{NaOH}$, jika $\mathrm{NaOH}$ telah diatas konsentrasi maksimal, peningkatan $\mathrm{NaOH}$ akan menurunkan Derajat Subtitusi CMC akibat akses $\mathrm{NaOH}$ dengan $\quad \mathrm{ClCH}_{2} \mathrm{COONa}$ (Natrium monokloroaseatat) dalam media reaksi yang memicu terjadinya reaksi samping yaitu $\mathrm{HOCH}_{2} \mathrm{COONa}$ (natrium glikolat) [10].

Derajat substitusi mengalami penigkatan dipengaruhi oleh temperatur tertentu. Peningkatan temperatur yang terlalu tinggi mengakibatkan selulosa mengalami degradasi dimana selulosa tereliminasi oleh air secara kimiawi. Eliminasi terjadi pada interamolekul antara kelompok hidroksil sehingga menimbulkan hubungan silang dengan eter dan menurunkan gugus $-\mathrm{OH}$ pada selulosa untuk karboksimetilasi sehingga derajat subtitusi mengalami penurunan [8]. Kondisi terbaik yang dihasilkan pada konsentrasi $\mathrm{NaOH} 20 \%$, dan temperatur $45 \quad{ }^{\circ} \mathrm{C}$ dengan derajat subtitusi 0,8124 . Derajat subtitusi yang dihasilkan pada penelitian ini hampir mendekati dengan nilai derajat subtitusi yang dihasilkan puspamalar yaitu 0,821 [6].

Pengaruh Natrium Monokloroasetat dan Waktu Reaksi Terhadap Derajat Subtitusi Hubungan antara Natrium Monokloroasetat dan Waktu Reaksi Terhadap Derajat Subtitusi disajikan pada Gambar 2 .

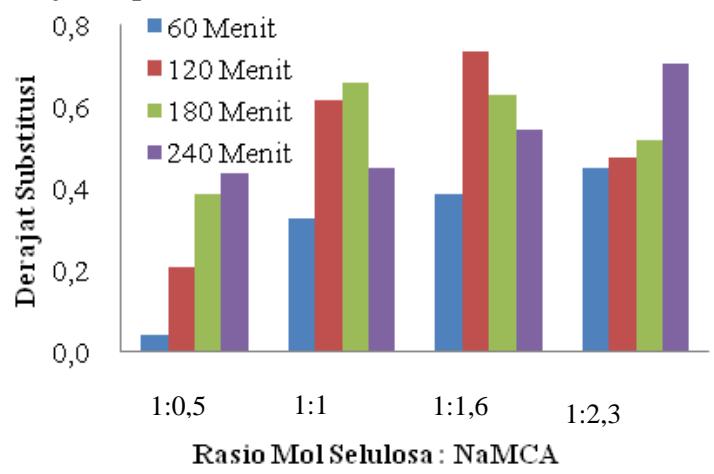

Gambar 2. Hubungan Derajat Subtitusi terhadap Natrium Monokloroasetat (Natirum monokloroasetat) dan Waktu Reaksi

Dari Gambar 2. dapat diliat bahwa semakin besar jumlah Natirum monokloroasetat yang digunakan maka derajat substitusi yang dihasilkan akan semakin meningkat hingga mencapai titik tertentu lalu mengalami penurunan Jika Natirum monokloroasetat yang ditambahkan berlebih maka sisa Natirum monokloroasetat bereaksi dengan $\mathrm{NaOH}$ membentuk $\mathrm{HOCH}_{2} \mathrm{COONa}$ (natrium glikolat) dan $\mathrm{NaCl}$ (natrium klorida) yang mengakibatkan turunnya derajat substitusi [4]. perlakuan agitasi yang semakin lama memungkinkan jarak antar gugus semakin lebar dan semakin melemahkan ikatan dan akan terputus sehingga substitusi yang diinginkan tidak terjadi [3].

Dapat dilihat bahwa kondisi terbaik yang diperoleh dalam peneitian ini adalah pada perbandingan rasio mol selulosa : Natirum monokloroasetat sebesar 1:1,6 dengan waktu reaksi 120 menit diperoleh derajat substitusi sebesar 0,734. Hal ini masih kurang baik dibandingkan dengan penelitian yang dilakukan oleh Pushpamalar, dkk., (2015) mengenai variasi massa Natirum monokloroasetat, dimana derajat substitusi yang terbaik yaitu 0,768 dengan rasio 
mol selulosa : Natirum monokloroasetat sebesar 1:1,6 dari dan waktu reaksi 180 menit [6].

\section{Analisis Sifat Fisik CMC}

CMC yang dihasilkan dengan salah satu run yang memiliki karaterisasi terbaik dibandingkan dengan standar SNI 06-373-1995 yang dapat dilihat pada Tabel 1 .

Tabel 1. Perbandingan Sifat Fisik CMC dengan standar SNI

\begin{tabular}{|l|c|l|}
\hline Parameter & $\begin{array}{c}\text { Hasil } \\
\text { penelitian }\end{array}$ & SNI \\
\hline $\mathrm{DS}$ & $0,73-0,81$ & $0,7-1.2$ \\
$\mathrm{Ph}$ & 7,4 & $6-8$ \\
Viskositas (cps) & 12,41 & $>25$ \\
\hline
\end{tabular}

Tabel 1. menunjukkan bahwa CMC yang dihasilkan telah memenuhi standar SNI untuk parameter DS dan $\mathrm{pH}$ sedangkan untuk parameter viskositas belum memenuhi standar SNI.

\section{Perbandingan CMC Penelitian Dengan CMC Komersial Menggunakan Alat} Spektrofotometer FTIR

Gambar 3. Perbandingan CMC Penelitian Dengan CMC Komersial Menggunakan Alat Spektrofotometer FTIR

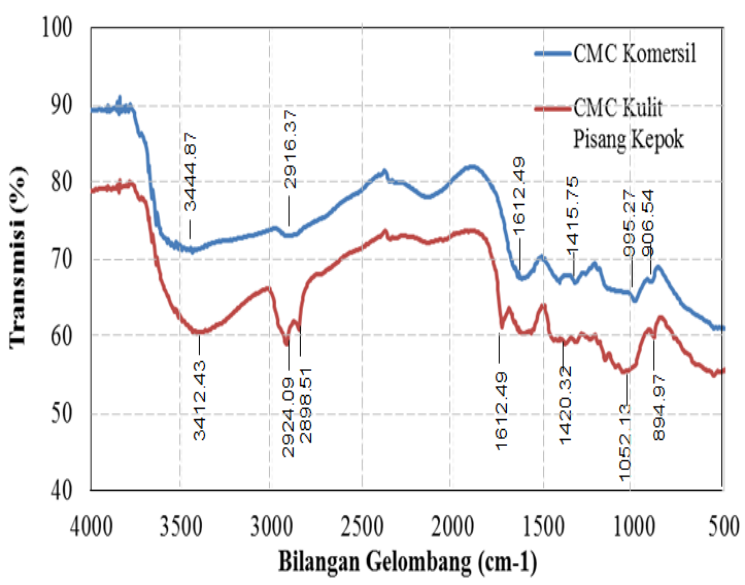

Gambar 3. Grafik FTIR CMC selulosa Kulit pisang Kepok dan Komersial

Pada gambar 3 dapat dilihat bahwa data spektrum infra merah karboksimetil selulosa kulit pisang kepok dan karboksimetil Selulosa komersial memiliki pola spektrum infra merah yang sama, yaitu gugus $\mathrm{O}-\mathrm{H}, \mathrm{C}-\mathrm{H}, \mathrm{C}=\mathrm{O}, \mathrm{CH}_{2}$, C-O dan 1,4 Bglikosida, Namun apabila dibandingkan dari hasilkan nilai transmisinya, nilai CMC komersial masih lebih baik yang menandakan kemurnian CMC komersial lebih tinggi dibandingkan dengan CMC penelitian. Dan kemurnian erat hubungannya dengan kelarutan CMC dalam air yang juga berdampak pada kualitas CMC sehingga menurunkan viskositas CMC yang dihasilkan.

\section{Kesimpulan}

Adapun kesimpulan yang dapat diambil dari penelitian ini adalah :

1. Kondisi terbaik yang diperoleh pada penelitian ini, untuk tahap alkalisasi yaitu pada temperatur $45{ }^{\circ} \mathrm{C}$ pada konsentrasi $\mathrm{NaOH} 20 \%$ dengan derajat subtitusi yang dihasilkan yaitu 0,812 sedangkan untuk tahap karboksimtilasi diperoleh hasil derajat subtitusi tertinggi yaitu 0,73 pada rasio mol selulosa:NaMCA 1:1,6 dan waktu reaksi, untuk viskositas yang dihasilkan mencapai 12,4 cps dan $\mathrm{pH}$ netral yaitu 7,4.

2. Hasil FTIR yang terdapat pada karboksimethil selullosa kulit pisang kepok yaitu gugus $\mathrm{O}-\mathrm{H}, \mathrm{C}-\mathrm{H}, \mathrm{C}=\mathrm{O}, \mathrm{CH}_{2}$, $\mathrm{C}-\mathrm{O}$ dan 1,4 $\beta$ glikosida, dan gugus gugus ini sama dengan hasil FTIR untuk CMC komersial

\section{Ucapan Terimakasih}

Pelaksanaan penelitian ini tidak terlepas dari bantuan berbagai pihak, peneliti menyampaikan penghargaan dan rasa terimaksih yang sedalam dalamnya kepada seluruh orang yang senantiasa memberikan dukungan / dorongan moril maupun materil hingga selesainya penelitian ini.

\section{Daftar Pustaka}

[1] BPS, Buletin Statistik Perdagangan Luar Negeri, Badan Pusat Statistik, JakartaIndonesia, Halaman 62, 2006.

[2] F. Rodiyatul, L. Harianie M.P, M.Ahmad, M.Sc. Pengaruh Suhu dan $\mathrm{pH}$ terhadap Aktivitas Enzim Selulase dari Kultur Campuran Trichoderma sp, Gliocladium sp, dan Botrytis sp. yang ditumbuhkan pada Media Kulit Pisang, Skripsi S1, Jurusan Biologi, Fakultas Sains dan Teknologi, Universitas Islam Negeri Maulana Malik Ibrahim, Malang, 2014.

[3] N. Dianrifiya dan Putri, Rukmi, Pemanfaatan Selulosa Dari Kulit Buah Kakao (Teobroma Cacao L.) Sebagai Bahan Baku Pembuatan CMC (Carboxymethyl Cellulose) Cellulose Utilization In Cacao Pod Husk (Theobroma Cacao L.) As Raw Material For CMC 
(Carboxymethyl Cellulose) Synthesis, Jurnal Pangan Dan Agroindustri.Jurusan Teknologi Hasil Pertanian, 2014, Vol.2 No.3, Halaman 34-42.

[4] Ott and Spurlin, Cellulose and Cellulose Derevative Part II, Penerbit Interscience Publishers Inc., Osmania Univerity, 1995, Halaman 271.

[5] Pitaloka, A. Badra, N. Anis, A. Handaya, M. Nasikin, Pembuatan CMC Dari Selulosa Eceng Gondok Dengan Media Reaksi Campuran Larutan Isopropanol-Isobutanol Untuk Mendapatkan Viskositas Dan Kemurnian Tinggi, Jurnal Integrasi Proses, 2015, Volume 5. No.2. Halaman 108-114.

[6] V.Pushpamalar, S.J Langford, M. Ahmad, Y.Y. Lim, Optimized Of Reaction Condition For Preparing Carboxymethyl Cellulose From Sago Waste, 2005, Halaman 312-318.

[7] Pusat Data dan Sistem Informasi Pertanian Sekretariat Jendral - Kementrian Pertanian, Outlook Komoditi Pisang, ISSN 19071507, 2014, Halaman 1-90.

[8] J. Scheirs, G. Camino, dan W.Tumiatti, Overview of water evolution during the thermal degradation of cellulose. European Polymer Journal, 2001, Volume 37, Halaman 933-942.

[9] Witono, R Judi, Okky dan A. Dewi, Kajian Awal Terhadap Pembuatan Carboxymethyl Starch (CMS) dari Umbi Pati, Garut. Jurnal, 2004, ISSN : 14114216.

[10] J. Zhang, D. Li, X. Zhang, Y. Shi, Solvent Effect on Carboxymethylation of Cellulose, Journal of Applied Polymer Science, 1992, Volume 49, Halaman 741 - 745. 